Journal of Social and Development Sciences

Vol. 1, No. 2, pp. 74-78, Mar 2011

\title{
Study of Operating and Marketing Strategy Factors in the Formulation of Strategies of Small Manufacturers
}

\author{
Seyed Mohammad Abdollahi Keyvani \\ Management Department Islamic Azad University, Karaj branch, Iran \\ smakeyvani@yahoo.com
}

\begin{abstract}
The main purpose of this research is to measure the relative importance of a selected number of primary operating and marketing factors which may be involved in the formulation of strategies of small manufacturers. One hundred manufacturing owner-managers in Iran were investigated. The marketing factors emphasized most often were improvement in product quality and reduction in product cost. However, improvements in customer service and in scheduling appeared to contribute more to actual firm performance. Overall, there seemed to be more emphasis on the production strategy factors than marketing factors as a means to gaining competitive advantage.
\end{abstract}

Keyword: Marketing strategy, formulation of strategies, small manufacturing firms, marketing factor.

\section{Introduction}

Measuring the relative importance of primary operating and marketing factors may be involved in the formulation of strategies of small manufacturers. The marketing factors emphasized most often were improvement in product quality and reduction in product cost. However, improvements in customer service and in scheduling appeared to contribute more to actual firm performance. Overall, there seemed to be more emphasis on the production strategy factors than marketing factors as a means to gaining competitive advantage. It is useful to consider strategy formulation as part of a strategic management process that comprises three phases: diagnosis, formulation, and implementation. Strategic management is an ongoing process to develop and revise future-oriented strategies that allow an organization to achieve its objectives, considering its capabilities, constraints, and the environment in which it operates (Williams, 2002; Harrison and frank, 1999; McCall et al., 1990; Porter, 1985, 1980).

\section{Diagnosis includes}

1. Performing a situation analysis (analysis of the internal environment of the organization), including identification and evaluation of current mission, strategic objectives, strategies, and results, plus major strengths and weaknesses.

2. Analyzing the organization's external environment, including major opportunities and threats.

3. Identifying the major critical issues, which are a small set, typically two to five, of major problems, threats, weaknesses, and/or opportunities that management require should be have particularly high priority attention.

\section{Formulation}

The second phase in the strategic management, process produces a clear set of recommendations, with supporting justification, that revise as necessary the mission and objectives of the organization, and supply the strategies for accomplishing them. In formulation, we are trying to modify the current objectives and strategies in ways to make the organization more successful. This includes trying to create "sustainable" competitive advantages, although most competitive advantages are eroded steadily by the efforts of competitors. A good recommendation should be: effective in solving the stated problem(s), practical (can be implemented in this situation, with the resources available), feasible within a reasonable time frame, costeffective, not overly disruptive, and acceptable to key "stakeholders" in the organization. It is important to 
consider "fits" between resources plus competencies with opportunities, and also fits between risks and expectations.

There are four primary steps in this phase:

1. Reviewing the current key objectives and strategies of the organization, which usually would have been identified and evaluated as part of the diagnosis

2. Identifying a rich range of strategic alternatives to address the three levels of strategy formulation outlined below, including but not limited to dealing with the critical issues

3. Doing a balanced evaluation of advantages and disadvantages of the alternatives relative to their feasibility plus expected effects on the issues and contributions to the success of the organization

4. Deciding on the alternatives that should be implemented or recommended

In organizations, and in the practice of strategic management, strategies must be implemented to achieve the intended results. The most wonderful strategy in the history of the world is useless if not implemented successfully. This third and final stage in the strategic management process involves developing an implementation plan and then doing whatever it takes to make the new strategy operational and effective in achieving the organization's objectives.

\section{Literature Review}

Until recently, manufacturing factors have been given much less attention than marketing factors as a key element in successful company strategy. Wickham Skinner argued that manufacturing was a "missing link" in company strategy and he suggested that "executives tend to avoid involvement in manufacturing policy making, and manufacturing managers are ignorant of corporate strategy and a function that could be a valuable asset and tool of corporate strategy becomes a liability instead (Skinner, 1985). Hayes and Wheelwright (1984) suggest that "there has been a growing recognition that manufacturing can be a formidable competitive weapon if equipped and managed properly, and that a key to doing that is the development of a coherent manufacturing strategy." In addition, they argue that competitive strategy can only be successful when manufacturing strategy operates in concert with the other functional strategies. A more recent study found that the top executives of manufacturing firms emphasize quality/ reliability (first priority in $55 \%$ of the cases) and to a lesser degree customer service factors (21\% of cases) in their company strategies (Hanna and Michael, 1989). However, these studies were made among large firms. We undertook this research to determine the degree to which top management in smaller firms perceive the roles of a selected number of manufacturing and marketing factors in their overall company strategies. We would expect that manufacturing factors would be given considerable importance in company strategy in many companies since typically the owners of small manufacturing firms have their background in technical areas. However, we were interested in identifying which particular factors within the manufacturing area are emphasized and the relative importance of marketing factors in company strategy.

\section{Methodology}

Owner-managers in 100 firms were interviewed in 5 industrial classifications in Iran. The total number of firms in each classification ranged from 9 to 14. Product lines included apparel, fabricated metal, auto parts, electronics and instruments. The level of technological change experienced by these firms was categorized into 3 levels: relatively low change (apparel and metal fabrication), medium change (auto parts), and relatively high change (electronics and instruments). There was a relatively high level of agreement among respondents within these 3 groups concerning the rate of change (chi square $=8.41, \mathrm{p}<.05$ ). Companies ranged in size from 10 to 250 employees and were a minimum of 3 years old. Each respondent was asked to describe and categorize the firm's attempts to improve performance over the past year by making changes in operations and marketing areas. He was then asked to indicate the degree of effort in each category (from little or none to extensive). Secondly, these efforts were ranked in the order of their actual contribution to improved firm performance. Table 1 reports the frequencies for each factor in the two areas. 
Table 1: Relative importance of tactical changes implemented by firms

\begin{tabular}{lc}
\hline The main objective /frequency \\
\hline Operations Number of Times Ranked as Factors Most Important (n=95) \\
Improve Product Quality & 29 \\
Reduce Product Cost & 21 \\
Improve Product Design & 12 \\
Improve Service & 9 \\
Improve Inventory Control & 8 \\
Reduce Lead Times & 7 \\
Improve Scheduling & 3 \\
Improve Materials Handling & 2 \\
Marketing Factors & $(\mathrm{n}=82)$ \\
Development of New Markets & 19 \\
Change in Pricing & 18 \\
Change in Product Line & 16 \\
Increased Sales Effort & 13 \\
Changes in Promotion & 10 \\
Improvement in Service Offered & 6 \\
\hline
\end{tabular}

Improvement in product quality and reduction in product cost were the two strategy factors which were most often selected as the major contributors to improved firm performance (53\% of the firms responding). This result is supported by other studies concerning the importance of strategic factors in manufacturing (Pirnnejad et al, 2010; Hanna and Michael, 1989; Swamidass, 1986; Covin and Dennis, 1986; Schroeder, 1986; Avlonitis, 1985). On the other hand, in previous studies, customer service was given a high priority. In this study, less than $10 \%$ of the managers indicated that they considered customer service an important area for improvement. In the marketing area, there was a wider variation among firms with respect to the most important factors, and no particular strategies appeared to be strongly preferred. Marketing services offered was considered important by only $7 \%$ of the respondents. This result is similar to the ranking of "customer services" in the operations area.

\section{Operations and Marketing Relationships}

We also considered the degree to which firms that focused on a particular operations strategy factor would also have a preference for a particular factor or set of factors in the marketing area. The correlation matrix in Table 2 illustrates the relationships between these two sets of factors. For those firms which emphasized product quality there were no significant correlations with any of the marketing strategy factors used. On the other hand, for firms which emphasized reduction in costs, there was a corresponding emphasis on improving or increasing the sales (advertising/promotion) effort $(\mathrm{r}=.210, \mathrm{p}<.05)$. Firms which put a strong emphasis on the product design effort also emphasized three marketing strategy factors: changes in the product line $(r=.293, p<.005)$, increased sales effort $(r=.222, p<.05)$, and new market development $(\mathrm{r}=.251, \mathrm{p}<.01)$. This relationship seems logical, as the focus on product design and development will often lead to new markets or customers which have not been served previously. Alternatively, efforts to attract new markets and customers are likely to lead to the identification of opportunities for the design of new or improved products. 
Table 2: Correlation matrix of operation variables versus marketing variables

\begin{tabular}{ll}
\hline Product Quality & .148 .053 .001 .171 .132 .133 \\
Product Cost & .095 .033 .012 .116 .210 .004 \\
Product Design & .251 .046 .293 .222 .143 .067 \\
Service & .319 .059 .121 .295 .136 .668 \\
Inventory & .281 .145 .183 .278 .285 .168 \\
Lead Times & .019 .031 .198 .060 .146 .239 \\
Scheduling & $.114-.149 .046 .228 .136 .198$ \\
Raw Materials & .117 .145 .121 .331 .079 .047 \\
Material Hand & .372 .046 .244 .213 .149 .198 \\
\hline
\end{tabular}

In addition, fairly strong relationships were found between improvements in inventory control and changes in the product line $(r=244, p<.01)$ and changes in inventory control and development of new markets/customers $(\mathrm{r}=.372, \mathrm{p}<.001)$. This relationship is likely the result of recognition by many firms that their inventory control systems were no longer adequate or appropriate as product lines were extended and new markets developed. The relative importance of these operations and marketing strategy factors for firm performance was also tested. The results of a multiple regression analysis, using actual sales growth as the dependent variable, indicated that the most productive strategy factors were improvements in service to the customer, improvements in raw material quality and improvement in scheduling. However, these strategies appeared to benefit only those firms where:

1. Overall industry demand was growing.

2. There was considerable technological change occurring in the industry.

Surprisingly, emphasis on the marketing strategy factors did not appear to be a major contributing factor in sales growth. Improvement in service to the customer, however, is also an operations factor which may have a considerable marketing component as well. Finally, an attempt was made to determine the existence of links between the strategy factors and profitability. However, it was difficult to establish the validity of the data on profitability. Questions concerning profitability were asked in the interviews, but no published financial statements were available. The relationship was not found to be significant and the total amount of variance explained was small.

\section{Conclusions and Suggestion for Future Research}

Both improvement in product quality and reduction in product cost were considered highly important manufacturing strategy factors for a majority of small manufacturing firms. However, it must be pointed out that a considerable number of firms put more emphasis on other factors, such as improving product design, inventory control and reducing lead times. It also appeared that emphasis on a particular operations factor is often combined with specific marketing activities, for example, product design with increased efforts in sales and in developing new markets and customers. Overall, there seemed to be more emphasis on the production strategy factors than in the marketing area by management of these firms. One possible explanation is that for the time period covered by the study, the operations area is the one most in need of improvement, and thus, managers are focusing their efforts more in this area. And generally was the person responsible for negotiating sales contracts. Our results did not indicate that any of the firms were particularly weak in the marketing of their products. We did not directly evaluate a firm's marketing or operations capabilities. Our questions concerned what combined and incremental actions were taken by management in these strategic areas to improve a product line's performance. A further explanation for the low ranking of marketing as a tool for improving the performance of small manufacturers is the appearance of a reactive rather than proactive approach to strategy. For the most part we found that these firms operate in a production rather than a marketing mode where activities such as product development, pricing, promotion and distribution tend to be integrated within the functional area of operations. As a result, marketing decisions tend to be subordinated, and an operations slant is given to tactical decisions when reacting to competitive pressures within the industry. A survey similar to this which samples larger manufacturers may very well reveal a more 
offensive or "proactive" (rather than defensive) approach where marketing plays a much stronger role in strategic planning. Another finding was the link between a number of operations strategy factors and sales growth. Alternatively, the links between the marketing and performance were not significant. Wheelwright (1985) argues that "all functions should work as a team" and the result will be an organization which uses its resources more efficiently. A similar theme is found in Haskins and Thomas (1988). They argue for the need to "break down the walls" between marketing and operations in order to develop a competitive advantage.

Suggestions for further research pertinent to the importance of operations and marketing strategy factors would include similar studies which would focus on a more homogenous sample. The relatively small number of firms in each industrial category made it necessary to generalize across a rather diverse set of companies. It was possible in this study to break down the sample into the generic categories of size and technological change. However, there are other contingency factors which have been shown to be potentially important in a study of this type. For example, owner- manager background and company goals are important determining factors in the choice of strategy. In addition, the success of a particular set of strategy factors depends upon a wide range of environmental and industry factors. Selection of a more homogenous sample, such as textile firms or auto parts, would facilitate a research design which could control for a larger number of contingency factors than was possible in this study.

\section{References}

Avlonitis, G. (1985). Revitalizing Weak Industrial Products, Industrial Marketing Management, 14: 92-105.

Covin, J. and Dennis S. (1988). Strategic Management of Small Firms in Hostile and Benign Environments, Strategic Management Journal, 3: 75-87.

Haskins, R. and Thomas P. (1988). Strategies for Entrepreneurial Manufacturing, Journal of Business Strategy, 11: 24-28.

Harrison, E and Frank, M. (1999). The Managerial Decision-Making Process (5 $5^{\text {th }}$ Ed.). Boston: Houghton Mifflin.

Hayes, R. H. and Wheelwright, S. C. (1984). Restoring Our Competitive Edge: Competing Through Manufacturing, New York: John Wiley and Sons.

Hanna, M. and Michael, S. (1989). The Relative Importance of Manufacturing Strategy Factors, Proceedings of Southeast, TIMS.

McCall, M.W., Kaplan, j. and Robert, K. (1990). Whatever it takes: The realities of managerial decision making ( $2^{\text {nd. }}$ Ed.), Englewood Cliffs, NJ: Prentice-Hall.

Paul M. (1986). Manufacturing Strategy: Its Assessment and Practice, Journal of Operations Management, 6(4): 471-484.

Pirnnejad, A., Salami, H. and Abdolazim, M., (2010). Outsourcing priorities of government functions: Analytic Network process approach, African journal of business management, 4(9): 1723-1735.

Porter, M. E. (1980). Competitive Strategy: Techniques for analyzing industries and competitors. New York: Free Press.

Porter, M. E. (1985). Competitive advantage: Creating and sustaining superior performance. New York: Free Press.

Skinner, W. (1985). Manufacturing: The Formidable Competitive Weapon. New York: John Wiley.

Schroeder, R. G. (1986). The Content of Manufacturing Strategy: An Empirical Study, Journal of Operations Management, 6(4): 104-114.

Swamidass, P. M., (1986). Manufacturing Strategy: Its Assessment and Practice, Journal of Operations

Management, 6(4): 471-484.

Wheelwright, S. (1985). Restoring the Competitive Edge in U.S. Marketing, California Management Review, 27(3): 26-42.

Williams, S. W. (2002). Making better business decisions: Understanding and improving critical thinking and Problem solving skills, Thousand Oaks, CA: Sage Publications. 